\title{
Methodology for Development \\ of a 600-Year Tree-Ring Multi-Element Record \\ for Larch from the Taymir Peninsula, Russia
}

\author{
Alexi M. Grachev**, Eugene A. Vaganov ${ }^{\mathrm{a}}$, \\ Steven W. Leavitt , Irina P. Panyushkina ${ }^{\text {b }}$ \\ Eugene P. Chebykin ${ }^{c}$, Vladimir V. Shishova, \\ Natalia A. Zhuchenko ${ }^{c}$, Anastasia A. Knorred, \\ Malcolm K. Hughes ${ }^{b}$ and Mukhtar M. Naurzbaev \\ ${ }^{a}$ Siberian Federal University, \\ 79 Svobodny, Krasnoyarsk, 660041 Russia \\ ${ }^{b}$ Laboratory of Tree-Ring Research, University of Arizona, \\ Tucson, AZ 85721, USA \\ ${ }^{c}$ Limnological Institute $S B R A S$, \\ 3 Ulan-Batorskaya, Irkutsk 664033 Russia \\ ${ }^{d} V . N$. Sukachev Institute of Forest SB RAS, \\ 50/28 Akademgorodok, Krasnoyarsk, 660036 Russia
}

Received 17.05.2012, received in revised form 15.03.2013, accepted 22.03.2013

We developed a long (600-year) dataset for the concentrations of 26 elements in tree rings of larch from the Taymir Peninsula, the northernmost region in the world $\left(\mathrm{ca} .72^{\circ} \mathrm{N}\right)$ where trees grow. Tree rings corresponding to the time period from 1300 to 1900 A.D. were studied. Eleven wood strips, each from a different larch tree, were cut into ca. $100 \mathrm{mg}$ samples usually consisting of ten consecutive tree rings (but occasionally five). Between 19 and 40 consecutive samples resulted from each tree, yielding a total of 277 samples. The replication of each time interval ranged from three (for periods 1300-1400 A.D. and 1600-1700 A.D.) to six (for 1450-1600 A.D.). Wood samples were digested with concentrated $\mathrm{HNO}_{3}$ for measurement of $\mathrm{Li}, \mathrm{B}, \mathrm{Na}, \mathrm{Mg}, \mathrm{Al}, \mathrm{Si}, \mathrm{P}, \mathrm{Cl}$, $\mathrm{K}, \mathrm{Ca}, \mathrm{V}, \mathrm{Cr}, \mathrm{Mn}, \mathrm{Fe}, \mathrm{Co}, \mathrm{Ni}, \mathrm{Cu}, \mathrm{Zn}, \mathrm{As}, \mathrm{Rb}, \mathrm{Sr}, \mathrm{Y}, \mathrm{Zr}, \mathrm{Nb}, \mathrm{Mo}, \mathrm{Ag}, \mathrm{Cd}, \mathrm{Sn}, \mathrm{Sb}, \mathrm{I}, \mathrm{Ba}, \mathrm{La}, \mathrm{Ce}, \mathrm{Nd}$, $W, A u, P b, B i, T h$, and U using solution Inductively Coupled Plasma Mass Spectrometry (ICP$\mathrm{MS}$ ). Fourteen elements ( $\mathrm{V}, \mathrm{Co}, \mathrm{As}, \mathrm{Y}, \mathrm{Nb}, \mathrm{Mo}, \mathrm{Sb}, \mathrm{La}, \mathrm{Ce}, \mathrm{Nd}, \mathrm{W}, \mathrm{Au}, \mathrm{Th}$, and U) with extremely low concentrations were eliminated from consideration as unreliable. Here we report our sample preparation and measurement procedure, as well as the observed concentrations in tree rings, emphasizing considerations for developing representative and reliable denrodochemical datasets.

(C) Siberian Federal University. All rights reserved

* Corresponding author E-mail address: amgrachev@juno.com 
Keywords: Dendrochemistry, Larix gmelinii, elements, tree rings, Taymir, ICP-MS.

\section{Introduction}

This work investigates the multi-elemental composition in tree rings of Dahurian larch (Larix gmelinii) from the Siberian Arctic near Khatanga at ca. $72^{\circ} \mathrm{N}, 102^{\circ} \mathrm{E}$ (Fig. 1). It has long been recognized that the tree-ring archive can capture changes in the chemical environment related to atmospheric chemistry, biogeochemical cycling and climate influences (see e.g., Baes, McLaughlin, 1984; Hantemirov, 1991; 1992; 1996; Padilla, Anderson, 2002 and references therein).
Seasonal and long-term tree growth of larch at the site of this study is strongly limited by temperature (Naurzbaev et al., 2003). Elemental composition of tree rings has not been studied at this location since the 1980's (Adamenko et al., 1985; Chetverikov, 1986), and of course the analytical capabilities have improved tremendously since then. Siberian Arctic tree rings have recently been used to extensively investigate other tree-ring variables: tree-ring width (Vaganov et al., 1996, 1999; Hughes et al., 1999), maximum latewood density (Briffa

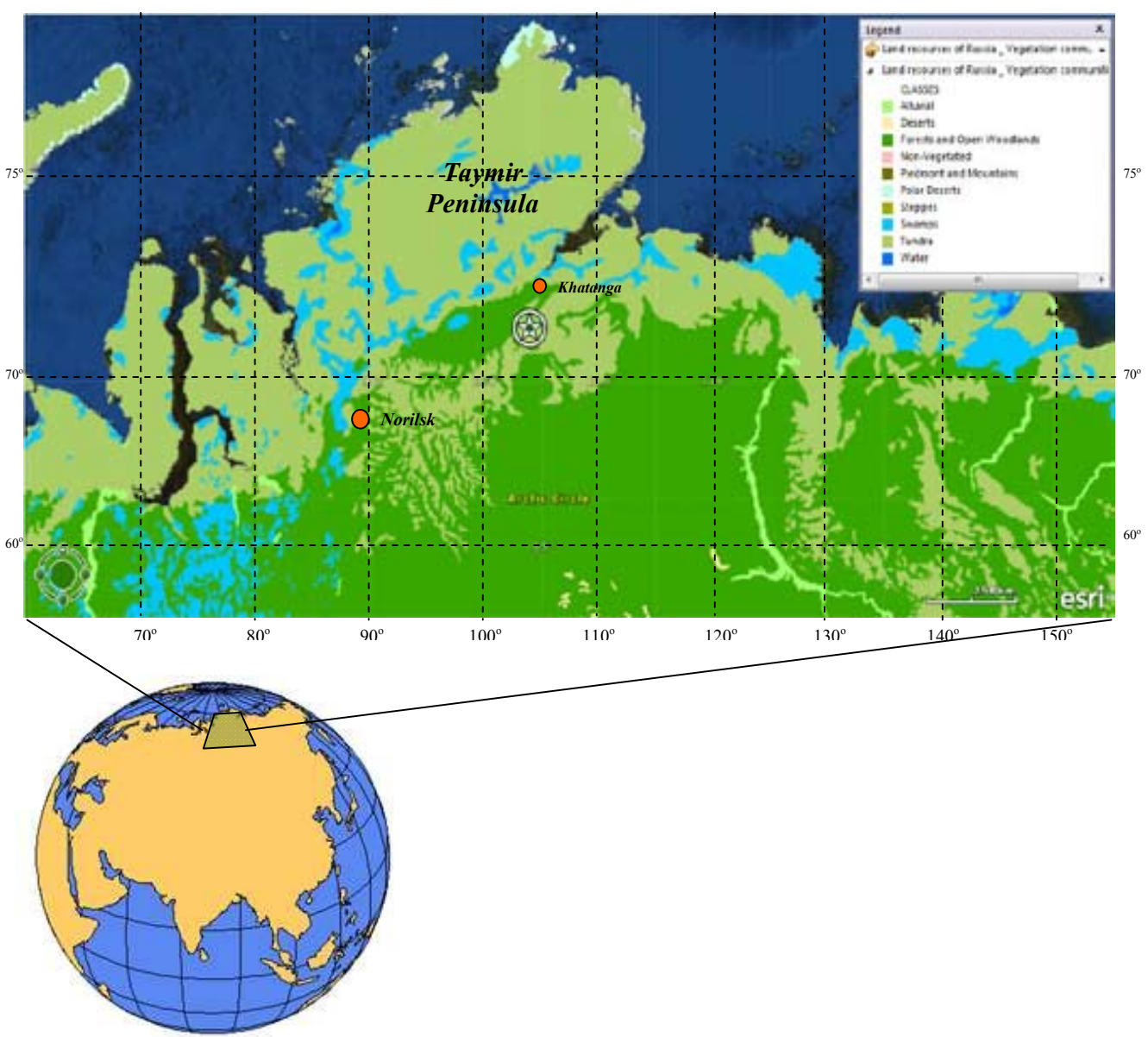

Fig. 1. Approximate location of sampling site on the Taymir Peninsula marked with a star immediately south of the town of Khatanga. The city of Norilsk is to the southwest of the sampling site 
et al., 1998, 2001, 2004; Esper et al., 2010), tracheid dimensions (Silkin, Kirdyanov, 2003; Panyushkina et al., 2003) and stable isotopic composition (Kirdyanov et al., 2008; Sidorova et al., 2010). It is desirable to precisely measure as many parameters as possible on each tree ring and to understand controls on each parameter to make more accurate reconstructions of past environmental conditions (Hughes, 2002).

Solution inductively coupled plasma mass spectrometry (ICP-MS) used in this study allows a wide range of elements to be measured at the same time. However the dissolution of samples is a very laborious procedure involving many steps, including the need to weigh samples with high precision multiple times at different stages. The method was applied to tree rings for the first time in the work of Hall et al. (1990). The first report of application of another high-sensitivity method, solution inductively coupled plasma atomic emission spectrometry (ICP-AES) to tree-ring analyses in Russia was made in 1990 by R M. Hantemirov (Hantemirov, 1992). Since then a number of studies using the solution ICP-MS method have appeared in literature (e.g., Yu et al., 2007; Rothpfeffer, Karltun, 2007; Kirchner et al., 2008). Solution ICP-MS should be distinguished from laser ablation ICPMS (e.g., Monticelli et al., 2009), which is less laborious but less precise.

We measured samples over the last 600 years, making the element series reported in this work the longest ever developed. The dataset presented here was obtained to investigate multielemental composition in tree rings over a long period in a very remote site in the Siberian Arctic to document inter-tree variability in long element time series. This paper reports the methodology and presents concentrations of elements in tree rings, whereas a subsequent paper (Panyushkina et al., in prep.) will analyze and interpret the observed trends of the elements.

\section{Materials and Methods}

Field sampling

In 2006, cross-sections (discs) of 11 larch (Larix gmelinii) trees were collected from the Taymir peninsula near Khatanga. All tree samples were from dead trees collected at a site at $70^{\circ} 53^{\prime} \mathrm{N} 102^{\circ} 55^{\prime} \mathrm{E}$ (ca. $350 \mathrm{~m}$ a.s.l.) on the Kotuy River (Fig. 1). This location has a strong seasonal climate, with the mean annual temperature of $-13^{\circ} \mathrm{C}$, January temperature of $-42^{\circ} \mathrm{C}$ (minimum) and $-20.4^{\circ} \mathrm{C}$ (maximum), and July temperature of $18.3^{\circ} \mathrm{C}(\max )$ and $7.9^{\circ} \mathrm{C}(\mathrm{min})$ based on data from the nearest meteorological station Khatanga $\left(71^{\circ} 98^{\prime} \mathrm{N} 102^{\circ} 47^{\prime} \mathrm{E}, 30 \mathrm{~m}\right.$ a.s.l.) for the period 1947-2006. This area receives an average of $254 \mathrm{~mm}$ of precipitation annually, ca. $105 \mathrm{~mm}$ of which falls in the growing-season months of June, July and August.

\section{Laboratory subsampling}

Since 2006 the cross-sections were stored in a wood depository (dry conditions, room temperature) until the chemical processing. The work proceeded in several stages, the first of which involved surfacing each of the 11 cross-sections with progressively finer sandpaper to increase visibility of rings. Subsequently one wood strip was cut out of each cross-section (Fig. 2). Ringwidth measurements and dating were performed on each of eleven wood strips from the crosssections on the Lintab workstation (Rinntech ${ }^{\circledR}$, Germany) with TSAP-Win crossdating software

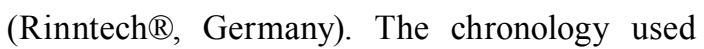
in this work is the same as in Naurzbaev and Vaganov (2000).

The eleven wood strips were subsequently transported to the Institute of Geochemistry SB RAS (Irkutsk) where they were processed in the Grade-1000 clean room according to the following procedure. First, each surface on the wood strips cut from the cross-sections was cleaned with a stainless-steel scalpel. It should be 


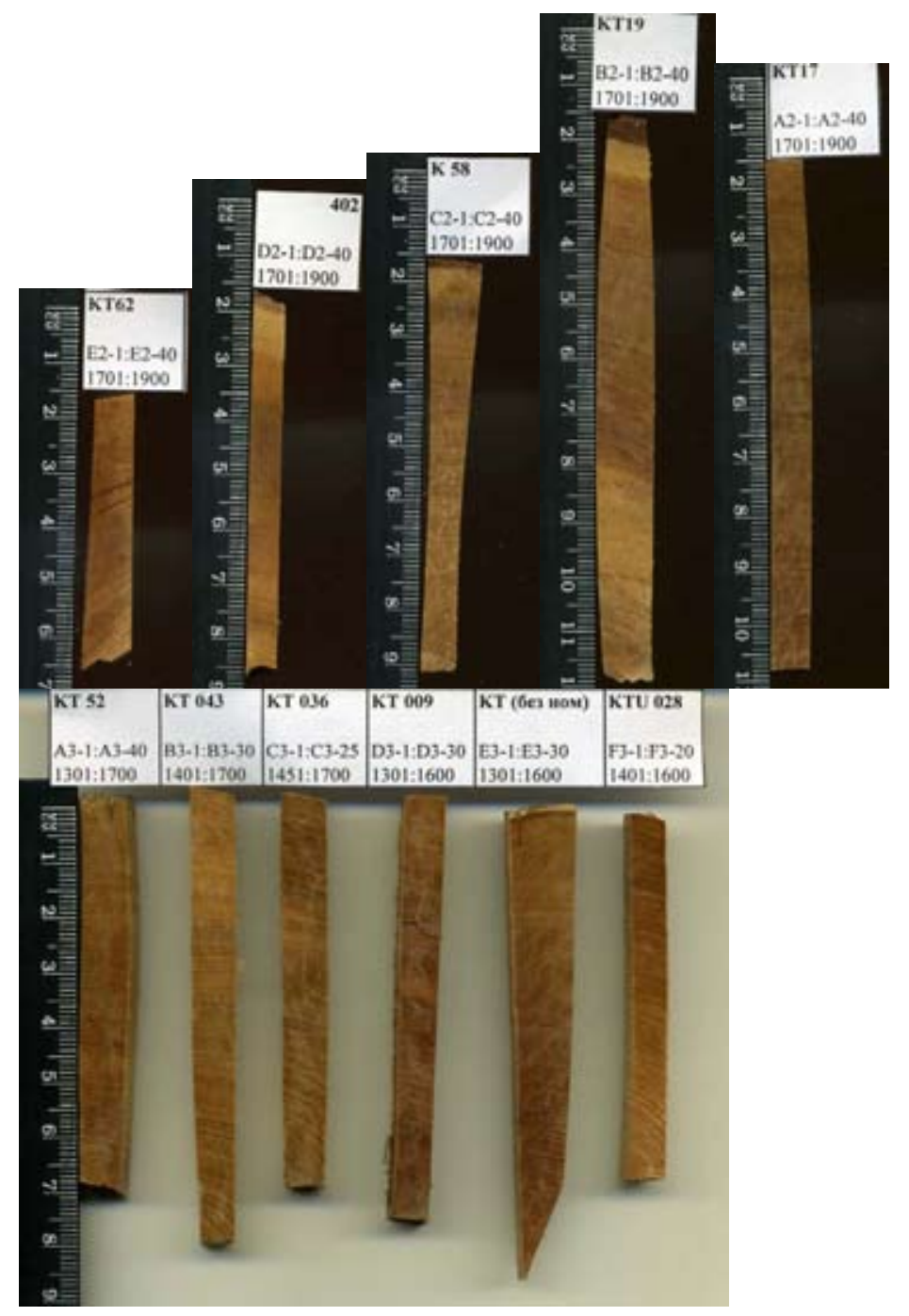

Fig. 2. Photographs of the 11 wood strips that were analyzed in this work. The labels indicate the time range covered by each wood strip

noted that the blades on the scalpel were replaced after cleaning a wood strip and subsequently cutting it into pieces (see below). Contamination of wood samples by razor blades was investigated in the work of Sheppard and Witten (2005), who found that laser-trimmed cores had less metal contamination than razor-trimmed cores. Because the razor blades were from the same batch from a single manufacturer and the physical contact of blades with the wood samples was similar for all samples, any contamination was deemed to be equal for all of the samples, and thus not affecting the trends observed.

Ten-year or five-year pieces were cut out from each wood strip with a scalpel under the microscope. Five-year pieces were cut only in cases where tree rings were wide (i.e., cumulative ring width of the five years exceeding ca. $3 \mathrm{~mm}$ ). If 5-year tree rings were narrow, it was very difficult to make an accurate cut and dry weight of an obtained piece was markedly lower than the desired $100 \mathrm{mg}$ for the analysis. Hence, 10-year 
samples were taken in most cases. Each sample was placed in a pre-weighed sterile polypropylene tube. Measuring element concentrations in 5 or 10ring samples has two advantages over measuring concentrations in single-year samples: i) reducing the influence of any potential contamination due to a greater sample mass, ii) removing biases that may affect a single ring due to elemental mobility by effectively averaging the concentrations over 5 or 10 rings.

A total of 277 samples were obtained with the following number of samples cut from each wood strip: 1) 23 samples with average ages 1703 to 1896 A.D., 2) 19 samples with average ages 1706-1896 A.D., 3) 20 samples with average ages 1706-1896 A.D., 4) 20 samples with average ages 1706-1896 A.D., 5) 20 samples with average ages 1706-1896 A.D., 6) 40 samples with average ages 1306-1696 A.D., 7) 30 samples with average ages 1406-1696 A.D., 8) 25 samples with average ages 1456-1696 A.D., 9) 30 samples with average ages 1306-1596 A.D., 10) 30 samples with average ages 1306-1596 A.D., 11) 20 samples with average ages 1406-1596 A.D.

\section{Chemical preparation and analysis}

The next step required digestion of the samples following the methodology described in Sheppard et al. (2008). Assuming that the carbon content in the samples is ca. $50 \%$ and that oxidation proceeds according to the reaction 4 $\mathrm{HNO}_{3}+\mathrm{C}=4 \mathrm{NO}_{2}+\mathrm{CO}_{2}$, we calculated the triple molar excess of nitric acid. For $100 \mathrm{mg}$ of wood, the required amount of $70 \% \mathrm{HNO}_{3}$ is ca. $4.5 \mathrm{~g}$ (or ca. $3.2 \mathrm{ml}$ ). All the chemical treatment of the samples henceforth was done at the Limnological Institute SB RAS (Irkutsk). The required volume of $70 \%$ nitric acid was added to each wood sample, and they were left at room temperature for 2.5 days. After this treatment the solutions became intensely yellow and the wood had the appearance of an almost transparent sponge, hardly visible in the solution. The closed tubes with the samples were then placed in an oven for 3 hours at $70^{\circ} \mathrm{C}$. At the end of each hour, the tubes were taken out from the oven and placed into the ultrasonic bath for 15 minutes. It should be pointed out that the dissolution appeared to be nearly complete after the first 1 hour in the oven. The tubes were then cooled to room temperature and the lids on them were slightly opened to release excess pressure from the gases that accumulated during the oxidation reaction. The tubes were then weighed in order to determine the loss of mass (as gas emitted). The loss of mass of the reactive solution was in most cases no more than $4 \%$. Subsequently, $1 \mathrm{ml}$ aliquots of the solutions were placed in 2-ml polypropylene tubes and were centrifuged for 10 $\min$ at $10000 \mathrm{~g}$. An aliquot of $120 \mu \mathrm{l}$ was placed into other pre-weighed 2-ml sample tube, into which $1.8 \mathrm{ml}$ of deionized water was then added, and the total mass of solution was determined. A solution of internal standard, indium, [In] $=193$ ppb, of $100 \mu$ l volume was added to the solutions. The total coefficient of dilution after all steps amounted to ca. 500 .

The concentrations of $\mathrm{Li}, \mathrm{B}, \mathrm{Na}, \mathrm{Mg}, \mathrm{Al}, \mathrm{Si}$, $\mathrm{P}, \mathrm{Cl}, \mathrm{K}, \mathrm{Ca}, \mathrm{V}, \mathrm{Cr}, \mathrm{Mn}, \mathrm{Fe}, \mathrm{Co}, \mathrm{Ni}, \mathrm{Cu}, \mathrm{Zn}, \mathrm{As}$, $\mathrm{Rb}, \mathrm{Sr}, \mathrm{Y}, \mathrm{Zr}, \mathrm{Nb}, \mathrm{Mo}, \mathrm{Ag}, \mathrm{Cd}, \mathrm{Sn}, \mathrm{Sb}, \mathrm{I}, \mathrm{Ba}, \mathrm{La}$, $\mathrm{Ce}, \mathrm{Nd}, \mathrm{W}, \mathrm{Au}, \mathrm{Pb}, \mathrm{Bi}$, Th, and $\mathrm{U}$ were measured on an Agilent 7500 quadrupole inductively coupled plasma mass spectrometer (ICP-MS) with the inert sample inlet system consisting of polypropylene spray chamber, polypropylene microflow concentric spray nebulizer $(180 \mu \mathrm{l} / \mathrm{min})$ and a platinum injector. A special configuration of the ICP-MS needed to measure $\mathrm{Hg}$ was not available, and therefore this element was not measured.

The element Se was also measured, but the observed concentrations did not significantly exceed the background values (the concentration in blank samples), and therefore the measured values are not reported. In order to calibrate the 
mass spectrometer, we used a multi-element standard solution "2A Standard" (concentrations in the standard were the following: $[\mathrm{Ag}],[\mathrm{Al}]$, [As], [Ba], [Be], [Ca], [Cd], [Co], [Cr], [Cs], [Cu], [Fe], [Ga], [K], [Li], [Mg], [Mn], [Na], [Ni], [Pb], $[\mathrm{Rb}],[\mathrm{Se}],[\mathrm{Sr}],[\mathrm{Tl}],[\mathrm{U}],[\mathrm{V}]$, and $[\mathrm{Zn}]=10.08 \mathrm{ppb}$, $[\mathrm{In}]=10.07 \mathrm{ppb},[\mathrm{Th}]=10.11 \mathrm{ppb})$. Additionally a standard of Lake Baikal water was used (for $\mathrm{Na}$, $\mathrm{Mg}, \mathrm{Si}, \mathrm{S}, \mathrm{Cl}, \mathrm{K}, \mathrm{Ca}$ ), referred hereafter as the control sample (Suturin et al., 2003). All other elements were calibrated using the algorithm of semi-quantitative analysis based on empirically selected sensitivity factors. The measurements were run in series as follows: control sample, 12 samples, control sample. Thorough rinsing of the whole system ( $3 \mathrm{~min}$ ) was performed before and after each control sample. Rinsing was not done between the samples because of the similarity of composition of the samples from adjacent wood pieces. Short rinsing of the autosampler needle (20 seconds) was done after each measurement. Metals having concentrations in excess of 0.1 ppb in solutions (or $0.05 \mathrm{ppm}$ referenced to the initial starting mass of dry wood sample) were measured with the uncertainty of no more than $30 \%$ ( $\mathrm{Na}, \mathrm{Mg}, \mathrm{Al}, \mathrm{K}, \mathrm{Ca}, \mathrm{Mn}, \mathrm{Fe}, \mathrm{Ni}, \mathrm{Cu}, \mathrm{Zn}$, $\mathrm{Rb}, \mathrm{Sr}, \mathrm{Pb}, \mathrm{Bi}$ ), which is typical for this method. The manufacturer of the ICP-MS instrument specifies that the uncertainty for the other elements (B, Si, P, S, Cl, Ti, V, Co, As, Br, Zr, $\mathrm{Nb}, \mathrm{Mo} \mathrm{Rh}, \mathrm{Pd}, \mathrm{Ag}, \mathrm{Cd}, \mathrm{Sn}, \mathrm{I}, \mathrm{Hf}, \mathrm{W}, \mathrm{Au}$ ) may in some instances exceed $30 \%$. All element concentrations are reported in units of ppb $(\mu \mathrm{g}$ per kg of dry wood).

\section{Results and Discussion}

A total of 11 wood strips from different trees were analyzed to obtain the 600-year elemental concentration record. The mean values and the range of concentrations for each element during the time interval 1300-1900 A.D. are given in Table 1. The concentration trends are shown in Fig. 3. Number of replicate trees corresponding to each year varied from three to six, i.e. each datapoint in Fig. 3 is an average of at least three values obtained independently for different trees. The large variability of values among different trees could be an indication that the microenvironmental effects on growth of specific trees (or differences in tree behavior more generally) may influence the level of element concentrations in tree rings to a greater extent than the broad changes in environmental conditions in the region. However, additional analyses are necessary to check contributing of possible flaws in our sample protocol to the discrepancies in concentration series among trees. In order to establish the nature and magnitude of variability of trace elements circumferentially and perhaps longitudinally in tree rings, a study such as that done for isotopes by Leavitt and Long (1984), is needed for microelements in tree rings.

Since the present paper is methodological, the discussion of the observed concentration trends, as well as of the sapwood- hardwood effect, age effect, etc. is outside the realm of this paper and will be addressed in a subsequent paper (Panyushkina et al., in prep.). The latter paper will also report statistical techniques helpful in interpreting the results presented here.

\section{Conclusions}

The longest published record of elements in tree rings (600 years) was obtained for the time period of 1300 to 1900 A.D. The set of the elements that was measured (40) is substantially greater than any previously reported. Our sample set is represented by eleven trees, which allowed good replication of each time interval between 1300 and 1900 A.D. (by 3-6 trees). We found that time series for most elements generally do not correlate well from tree to tree because of different individual physiological responses to environmental factors 
Table 1. Means and ranges (11 trees) of concentrations (ppm or mg per kg of dry wood) of elements in tree rings of larch from the Taymir Peninsula collected in 2006. Time interval is 1300-1900 A.D

\begin{tabular}{|c|c|c|c|}
\hline Element & Mean & Minimum & Maximum \\
\hline $\mathrm{Ca}$ & 770 & 440 & 1200 \\
\hline K & 300 & 220 & 350 \\
\hline $\mathrm{Cl}$ & 270 & 190 & 360 \\
\hline $\mathrm{Mg}$ & 250 & 150 & 370 \\
\hline $\mathrm{Si}$ & 140 & 110 & 150 \\
\hline $\mathrm{Na}$ & 42 & 24 & 75 \\
\hline $\mathrm{P}$ & 32 & 26 & 39 \\
\hline $\mathrm{Mn}$ & 14 & 6.2 & 20 \\
\hline $\mathrm{Fe}$ & 13 & 8.2 & 62 \\
\hline $\mathrm{Ba}$ & 12 & 8.0 & 15 \\
\hline $\mathrm{Sr}$ & 4.2 & 3.4 & 5.2 \\
\hline B & 3.2 & 2.3 & 5.1 \\
\hline $\mathrm{Zn}$ & 3.2 & 2.5 & 4.7 \\
\hline $\mathrm{Cu}$ & 2.4 & 0.65 & 8.7 \\
\hline $\mathrm{Al}$ & 1.7 & 1.0 & 3.2 \\
\hline $\mathrm{Bi}$ & 1.0 & 0.25 & 1.8 \\
\hline $\mathrm{Ni}$ & 0.59 & 0.21 & 1.9 \\
\hline $\mathrm{Rb}$ & 0.35 & 0.29 & 0.43 \\
\hline I & 0.21 & 0.10 & 0.38 \\
\hline $\mathrm{Pb}$ & 0.21 & 0.093 & 3.6 \\
\hline $\mathrm{Cr}$ & 0.19 & 0.12 & 1.7 \\
\hline $\mathrm{Li}$ & 0.11 & 0.063 & 0.42 \\
\hline $\mathrm{Ag}$ & 0.031 & 0.014 & 0.070 \\
\hline $\mathrm{Cd}$ & 0.015 & 0.008 & 0.036 \\
\hline $\mathrm{Zr}$ & 0.015 & 0.006 & 0.041 \\
\hline $\mathrm{Sn}$ & 0.014 & 0.006 & 0.048 \\
\hline
\end{tabular}

and chemical uptake or perhaps because of shortcomings in the experimental protocol. The studied tree-ring series show no trend related to tree age. Our subsequent paper (Panyushkina et al., in prep.) will contain a detailed discussion of this dendrochemical dataset based on statistical treatment.

\section{Acknowledgements}

Because the results presented in this paper would not have been possible without the initial idea of this work largely contributed by our friend and colleague Eugene L. Goldberg (deceased), we dedicate this paper to his memory.

We thank the U.S. Civilian Research and Development Foundation and the Russian Foundation for Basic Research for the support of this project (CRDF grant RUG1-2950KR-09, RFBR grant 09-04-92515-ИК_a to S. W. Leavitt and E. A. Vaganov). This work was also supported from the Fundamental Research Program №23 of the Presidium of the Russian Academy of Sciences (project №23.6, principal 

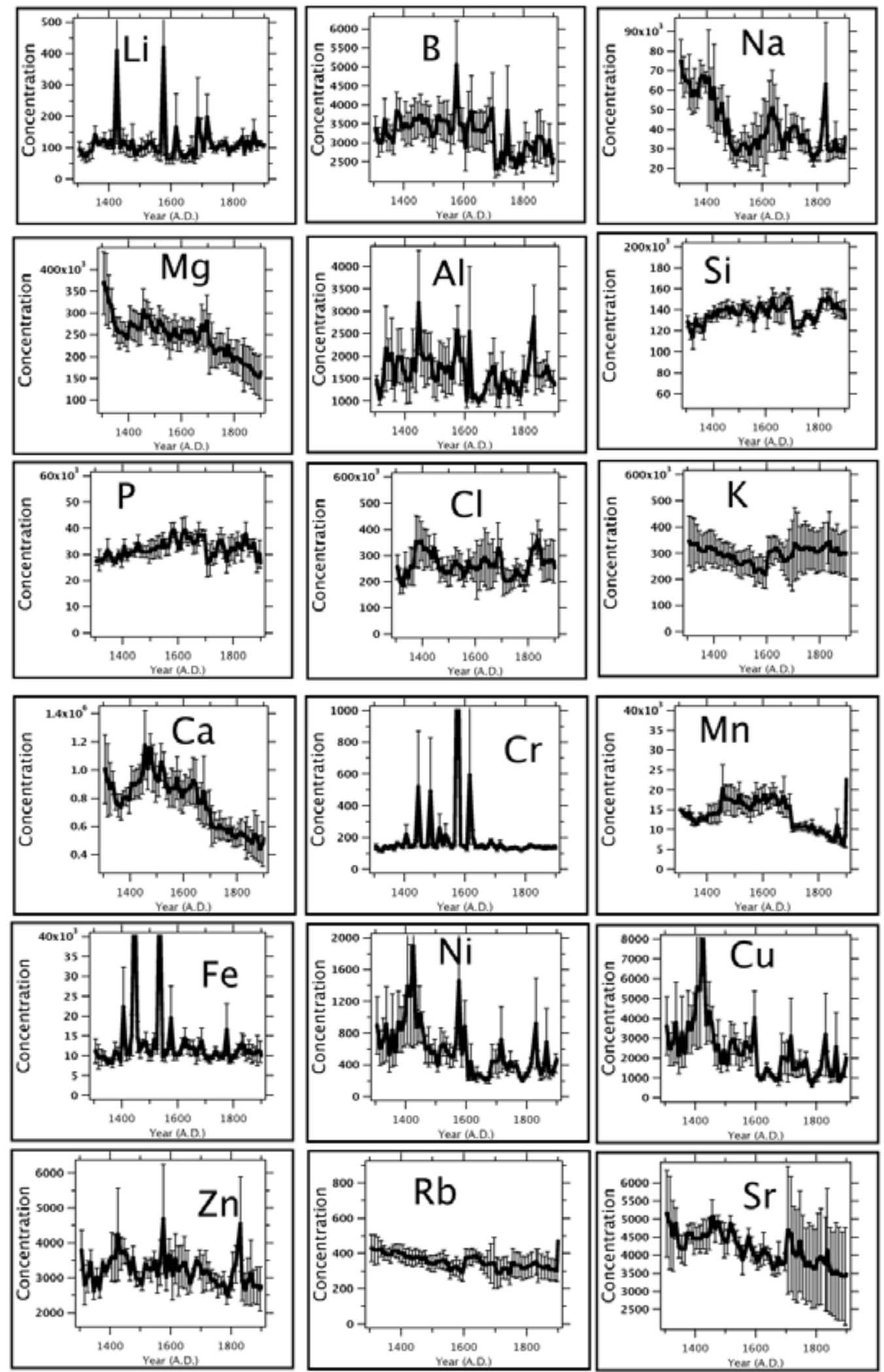

Fig. 3 

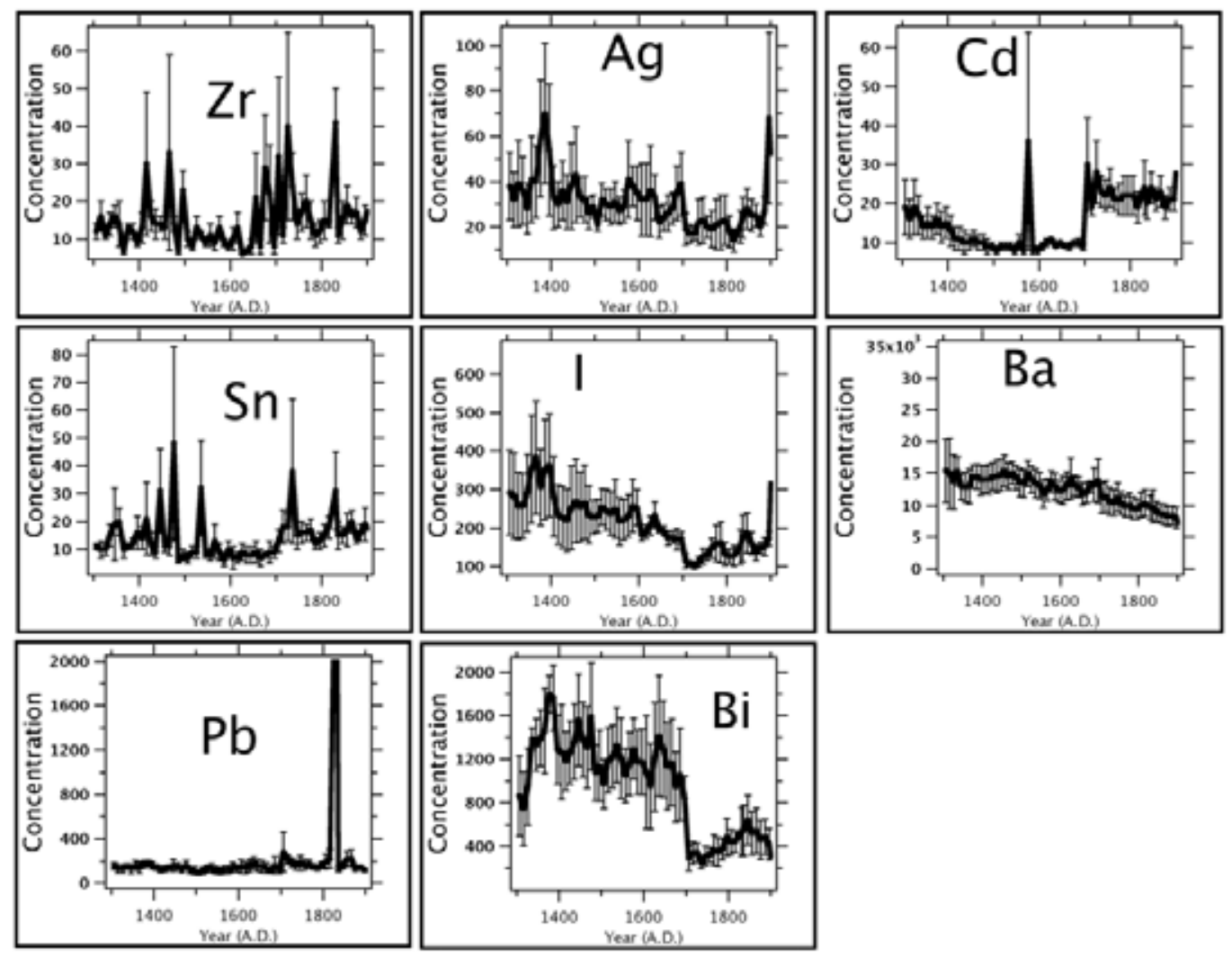

Fig. 3. The average concentrations of elements in tree rings of larch from the Taymir Peninsula collected in 2006 (bars indicate standard deviations of mean values)

investigators E. A. Vaganov and T. V. Khodzher), and a 1-year grant from the program of the Russian Ministry of Education and Science "Development of the Scientific Potential of the Institutions of Higher Learning" (awarded to the Siberian Federal University in 2011, principal investigator A. M. Grachev). We are grateful to Prof. R. M. Hantemirov (Institute of Ecology of Plants and Animals UB RAS) and Prof. N. N. Sushchik (Institute of Biophysics SB RAS) for reviewing this paper and providing valuable critical comments.

\section{References}

1. Adamenko V.N., Zhuravleva E.L., Chetverikov A.F. (1985) Chemical composition of annual tree rings and the condition of the natural environment. Doklady akademii nauk 265(2): 507-512.

2. Baes III C.F., McLaughlin S.B. (1984) Trace elements in tree rings: Evidence of recent and historical air pollution. Science 224: 494-497.

3. Blais J.M., Duff K.E., Laing T.E., Smol J.P. (1999) Regional contamination in lakes from the Noril'sk region in Siberia, Russia. Water, Air, and Soil Pollution 110: 389-404.

4. Briffa K.R., Schweingruber F.H., Jones P.D., Osborn T.J., Shiyatov S.G., Vaganov E.A. (1998) Reduced sensitivity of recent tree growth to temperature at high northern latitudes. Nature 391 : $678-682$. 
5. Briffa K.R., Osborn T.J., Schweingruber F.H., Harris I.C., Jones P.D., Shiyatov S.G., Vaganov E.A. (2001) Low-frequency temperature variations from a northern tree ring density network. J. Geophys. Res. 106: 2929-2941.

6. Briffa K.R., Osborn T.J., Schweingruber F.H. (2004) Large-scale temperature inferences from tree rings: a review. Global Planet. Change 40: 11-26.

7. Chetverikov A.F. (1986) Chemical composition of annual layers of tree growth and the conditions of the natural environment. In: Dendrochronology and Dendroclimatology. Novosibirsk: Nauka. P. 126-130 (in Russian).

8. Esper J., Frank D., Büntgen U., Verstege A., Hantemirov R.M., Kirdyanov A.V. (2010) Trends and uncertainties in Siberian indicators of 20th century warming. Global Change Biology 16: 386-398.

9. Hall G.S., Yamaguchi D.K., Rettberg T.M. (1990) Multielemental analyses of tree rings by inductively coupled plasma mass spectrometry. Journal of Radioanalytical and Nuclear Chemistry 146: 255-265.

10. Hantemirov R.M. (1991) The content of chemical elements in the annual layers of wood of Scots pine and possibilities for its use in retrospective bioindication of technogenic pollution. Ph.D. dissertation, Institute of Plant and Animal Ecology of the Ural Branch of the USSR Academy of Sciences, Sverdlovsk. 153 p.

11. Hantemirov R. (1992) Possibility to use chemical elements in tree rings of Scots pine for the air pollution reconstruction. In: Proceedings of the International Dendrochronological Symposium, Ystad, Sweden, 3-9 September 1990. LUNDQUA Report (editors: T.S. Bartholin et al.), vol. 34, Lund University, p. 142-145.

12. Hantemirov R.M. (1996) Bioindication of environmental pollution history through tree rings chemical analysis. In: Problems of Ecological Monitoring and Ecosystem Modelling. Vol. 16. St. Petersburg: Gidrometeoizdat, p. 153-164.

13. Hughes M.K., Vaganov E.A., Shiyatov S., Touchan R., Funkhouser G. (1999) Twentieth-century summer warmth in northern Yakutia in a 600 year context. The Holocene 9: 603-608.

14. Hughes M.K. (2002) Dendrochronology in climatology - the state of the art. Dendrochronologia 20: 95-116.

15. Kirchner P., Biondi F., Edwards R., McConnell J.R. (2008) Variability of trace metal concentrations in Jeffrey pine (Pinus jeffreyi) tree rings from the Tahoe Basin, California, USA. J. For. Res. 13: $347-356$.

16. Kirdyanov A.V., Treydte K.S., Nikolaev A., Helle G., Schleser G.H. (2008) Climate signals in treering width, wood density and $\delta^{13} \mathrm{C}$ from larches in Eastern Siberia (Russia). Chemical Geology 252: 31-41.

17. Leavitt S.W., Long A. (1984) Sampling strategy for stable carbon isotope analysis of tree rings in pine (Pinus edulis). Nature 311: 145-147.

18. Monticelli D., Di Iorio A., Ciceri E., Casteletti A., Dossi C. (2009) Tree ring microanalysis by LAICP-MS for environmental monitoring: validation or refutation? Two case histories. Microchim Acta 164: 139-148.

19. Naurzbaev M.M., Vaganov E.A. (2000) Variation of early summer and annual temperature in east Taymir and Putoran (Siberia) over the last two millennia inferred from tree rings. J. Geophys. Res. 105 (D6): 7317-7326. 
20. Naurzbaev M.M., Vaganov E.A., Sidorova O.V. (2003) Variability of air temperature in the north of Eurasia inferred from two-millennia tree-ring chronologies. Cryosphere of the Earth VII (2): 84-91 (in Russian).

21. Panyushkina I.P., Hughes M.K., Vaganov E.A., Munro M.A.R. (2003) Summer temperature in northern Yakutia since AD 1642 reconstructed from radial dimensions of larch tracheids. Canadian Journal of Forest Research 33: 1-10.

22. Rothpfeffer C., Karltun E. (2007) Inorganic elements in tree compartments of Picea abiesConcentrations versus stem diameter in wood and bark and concentrations in needles and branches. Biomass and Bioenergy 31: 717-725.

23. Sheppard P. R., Witten M. L. (2005) Laser trimming tree-ring cores for dendrochemistry of metals. Tree-Ring Research 61(2): 87-92.

24. Sheppard P.R., Ort M.H., Anderson K.C., Elson M.D., Vazquez-Selem L., Clemens A.W., Little N.C., Speakman R.J. (2008) Multiple dendrochronological signals indicate the eruption of Paricutin volcano, Michoacan, Mexico. Tree-Ring Research 64(2): 97-108.

25. Sidorova O.V., Siegwolf R.T.W., Saurer M., Naurzbaev M.M., Shashkin A.V., Vaganov E.A. (2010) Spatial patterns of climatic changes in the Eurasian north reflected in Siberian larch tree-ring parameters and stable isotopes. Global Change Biology 16(3): 1003-1018.

26. Silkin P.P., Kirdyanov A.V. (2003) The relationship between variability of cell wall mass of earlywood and latewood tracheids in larch tree-rings, the rate of tree-ring growth and climatic changes. Holzforschung 57: 1-7.

27. Suturin A.N., Paradina L.F., Epov V.N., Semenov A.R., Lozhkin V.I., Petrov L.L. (2003) Preparation and assessment of a candidate reference sample of Lake Baikal deep water. Spectrochimica Acta Part B 58: 277-288.

28. Vaganov E.A., Shiyatov S.G., Mazepa V.S. (1996) Dendroclimatic investigation in Ural-Siberian Subarctic. Novosibirsk: Nauka, 246 p. (in Russian)

29. Vaganov E.A., Hughes M.K., Kirdyanov A.V., Schweingruber F.H., Silkin P.P. (1999) Influence of snowfall and melt timing on tree growth in subarctic Eurasia. Nature 400(6740): 149-151.

30. Yu K.-F., Kamber B.S., Lawrence M.G., Greig A., Zhao J.-X. (2007) High-precision analysis on annual variations of heavy metals, lead isotopes and rare earth elements in mangrove tree rings by inductively coupled plasma mass spectrometry. Nucl. Instr. Meth. Phys. Res. (B) 255: 399-408. 


\title{
Методология получения 600-летней \\ многоэлементной летописи \\ на основе годичных колец лиственницы \\ с полуострова Таймыр, Россия
}

\author{
А.М. Грачев ${ }^{\text {, }}$ Е.А. Ваганов ${ }^{a}$, \\ С.У. Левитт ${ }^{\tilde{0}}$, И.П. Панюшкина ${ }^{\sigma}$, \\ Е.П. Чебыкин ${ }^{\text {, }, ~ В . В . ~ Ш и ш о в ~}{ }^{\text {a }}$ Н.А. Жученко \\ А.А. Кнорре \\ ${ }^{a}$ Сибирский федеральный университет, \\ Россия 660041, Красноярск, пр. Свободный, 79 \\ б Лаборатория изучения годичных колеч деревьев, \\ Университет Аризонь, \\ Тусон, Аризона 85721, США \\ в Лимнологический институт СО РАН, \\ Россия 664033, Иркутск, ул. Улан-Баторская, 3 \\ `Институт леса им. В.Н. Сукачева СО РАН, \\ Россия 660036, Красноярск, Академгородок, 50/28
}

\begin{abstract}
Нами был получен длительный массив данных (600 лет) концентраций 26 элементов в годичных кольцах лиственницы с полуострова Таймыр, самого северного региона в мире (около $72^{\circ}$ c.u.), где возможен рост деревьев. Изучались годичные кольиа, соответствуюшие промежутку времени с 1300 по 1900 год н.э. Одиннадцать древесных выпилов, по одному для каждой лиственницы, нарезались на образиы массой около 100 мг, которые, как правило, состояли из десяти годичных колеи (но в некоторых случаях из пяти). Из каждого дерева было получено от 19 до 40 последовательных образиов, что дало в общей сложности 277 образиов. Повторность для каждого временного интервала варьировала от трех (для периодов 1300-1400 г.н.э. и 1600-1700 г.н.э.) до шести (для периода 1450-1600 г.н.э.). Древесные образиы растворяли в концентрированной $\mathrm{HNO}_{3}$ для последующего измерения $\mathrm{Li}, \mathrm{B}, \mathrm{Na}, \mathrm{Mg}, \mathrm{Al}, \mathrm{Si}, \mathrm{P}, \mathrm{Cl}, \mathrm{K}, \mathrm{Ca}, \mathrm{V}$, $\mathrm{Cr}, \mathrm{Mn}, \mathrm{Fe}, \mathrm{Co}, \mathrm{Ni}, \mathrm{Cu}, \mathrm{Zn}, \mathrm{As}, \mathrm{Rb}, \mathrm{Sr}, \mathrm{Y}, \mathrm{Zr}, \mathrm{Nb}, \mathrm{Mo}, \mathrm{Ag}, \mathrm{Cd}, \mathrm{Sn}, \mathrm{Sb}, \mathrm{I}, \mathrm{Ba}, \mathrm{La}, \mathrm{Ce}, \mathrm{Nd}, \mathrm{W}, \mathrm{Au}, \mathrm{Pb}$, $B i$, Th и U при помощи масс-спектрометрии с индуктивно связанной плазмой (ICP-MS) для растворов. Четырнадцать элементов (V, Co, As, Y, Nb, Mo, Sb, La, Ce, Nd, W, Au, Th u U) с очень низкими концентрачиями были исключены из рассмотрения как недостоверные. В данной статье, основной целью которой являлась отработка методики получения репрезентативных и достоверных дендрохимических данных, приводится использованная нами процедура пробоподготовки и измерений, а также полученные концентрации в годичных кольцах.
\end{abstract}

Ключевые слова: дендрохимия, Larix gmelinii, элементы, годичные кольиа деревьев, Tаймыр, ICP-MS. 